SABINE JESNER

University of Graz, Southeast European History and Anthropology

sabine.jesner@uni-graz.at

\title{
PERSONNEL MANAGEMENT \\ DURING TIMES OF CRISIS. THE AUSTRIAN BANAT AND THE AUSTRO-RUSSIAN-TURKISH WAR (1736-1739)*
}

\begin{abstract}
This paper examines the Habsburg personnel policy in the Austrian Banat during and after the Austro-Russian-Turkish War (1736-1739). The war-ravaged region was affected massively by the confrontations between the Ottoman and Habsburg armies. Of central importance is the question how the Viennese court involved the local imperial civil and military personnel for war purposes. The investigation focuses on a range of tasks which had been conducted by low- and highranking officials as well as facets of personnel restructuring that became necessary during the conflicts and as repercussions of the war. Special attention is paid to the analysis of personnel management processes, which was made possible by the use of selected case studies.

Keywords: Personnel Policy, Banat of Temeswar, Austro-Russian-Turkish War (1736-1739), Bureaucracy, Crisis Management.
\end{abstract}

\section{Introduction}

I n May 1739 Johann Anton de Jean von Hansen (1686-1760), ${ }^{1}$ Administrative Council (Administrationsrat) in the Banat of Temeswar, ${ }^{2}$ wrote a heart wrenching letter addressed to his superior authority in Vienna. Five months before the end of the war he described his experiences during the last two years, which he spent continually in the region, in the midst of the theater of war and at constant risk of epidemics. These circumstances induced de Jean von Hansen to ask for a formally confirmed travel license to go for six weeks to Bratislava/Prešporok. Besides the load of his administrative duties during the three military campaigns of the Habsburg army against the Ottomans he lost his wife and

\footnotetext{
* This paper is funded by the Austrian Science Fund (FWF-Project P27488-G18).

${ }^{1}$ De Jean von Hansen was born in Lothringen. He was employed from 1704 to 1718 in imperial military service and worked since 1718 in civil service in the Banat. He held administrative positions in customs cooperation and mining before he became Administrative Council in 1733. He left the Banat in 1739. For biographical notes in this paper, if not otherwise mentioned, see Petri 1992.

${ }^{2}$ We will use the term Temeswar (Rom. Timişoara) for the city and Banat of Temeswar for the historical region.
} 
expressed concern at his two children in the unstable Banat and his declining state of health. ${ }^{3}$

De Jean von Hansen was part of the Banater Landesadministration (Provincial Government), which was established after the conquest of the Banat in 1716 by the Habsburg court, when the region was formed into a royal and chamber demesne. With the Treaty of Passarowitz/Požarevac (1718) the Banat as well as Lesser Wallachia (Oltenia) and northern Serbia with Belgrade became officially part of the Habsburg Monarchy. ${ }^{4}$ The newly conquered territories were incorporated into the administrative structure of the Habsburg Monarchy and the Banat, Serbia as well as Oltenia became separate provinces with a distinct, but differently structured administration. Responsible for the newly acquired territories was the Neoacquistische Subdelegation, a collegial conference body composed of members from the Court Chamber (Hofkammer) and the Aulic War Council (Hofkriegsrat). In the case of the Banat the Viennese court decided that the province should be managed by a combined civilian and military Landesadministration located in Temeswar. The Landesadministration was led by a presidium, which included both two civil Administrative Councils as well as the Commanding General, who functioned equally as Governor of the Banat and the Commander of the Fortress Temeswar (Festungskommandant). ${ }^{5}$ These key positions were assisted by a large number of staff in Temeswar as well as in the districts in the rural province of the Banat. In the following years the representatives of the crown tried to reorganize an underdevelopment region into an economically profitable one. ${ }^{6}$ The outbreak of the Austro-Russian-Turkish War (17361739) brought an abrupt end to these activities and the Viennese court was reminded of its defensive alliance with Russia signed on 6 August 1726, ${ }^{7}$ where the Emperor had promised auxiliary troops of 30,000 men in case of a hostile attack from a third party. ${ }^{8}$ The Habsburg Monarchy violated the Treaty of Passarowitz with the Ottoman Empire and joined the war in 1737.

While the course of the war, troop movement, military strategies and diplomatic history are well researched, ${ }^{9}$ this paper focuses on the strategies of the monarchy to use and involve the personnel employed in the Banat of Temeswar for war purposes. It will be outlined how the consequences of the war influenced the imperial personnel policy in the Banat and how personnel emerged actively. The study should be seen as part of the recently developed perspectives on the history of administration and bureaucracy, where the relationship between specific subjects as members of an institutionally defined group of actors and their institutional situation is moving into the foreground. ${ }^{10}$

Between the conquest and the outbreak of war in the Banat a collection of measures

\footnotetext{
${ }^{3}$ Letter from de Jean von Hansen to the Court Chamber from May 16, 1739. See OeStA FHKA NHK ABA9, June 1739, fol. 987r-989r.

${ }^{4}$ Ingrao, Samardžić and Pesalj 2011; Papacostea 1970: 36-63; Langer 1889: 155-247; Stefanovic-Vilovsky 1908.

${ }^{5}$ Regarding the Habsburg administration in the Banat of Temeswar see Kallbrunner 1958; Kucsko 1934; Mraz 1984 as well as Feneşan 1997.

${ }^{6}$ Jordan 1967.

${ }^{7}$ Parvev 1995: 199-200.

${ }^{8}$ Hochedlinger 2003: 213.

${ }^{9}$ For instance Angeli 1881: 247-338, 409-479; Aksan 2013: 83-128; Roider 1982: 71-90.

${ }^{10}$ Becker and Krosigk 2008: 11-12; Brakensiek 2005: 297-326; Wendehorst 2015 or Reinhard 1996.
} 
was initiated and implemented to improve the economic competitiveness and the standard of living considerably, which ensured the sufficient subsistence of the population and strengthened the financial situation of the monarchy. Under supervision of the Banater Landesadministration the transport infrastructure and the postal service were reformed, factories were built, mining was modernized and marshland was drained. ${ }^{11}$ These targeted improvement measures were supported by the recruitment of highly qualified administrative personnel, workers and a strategic settlement of colonists. ${ }^{12}$ Since the start of the war most of the previous achievements were destroyed and would have had to be reconstructed after the end of the military conflicts.

The examined time span can be described as a critical phase or crisis. The term "crisis" is used as interdisciplinary and applicable. In the last four decades some theoretical approaches tried to define the term for historiography and to analyze "crisis" as a possible applicable methodical concept. ${ }^{13}$ In 1978 Rudolf Vierhaus uniquely defined a crisis as a process, where the beginning, culmination and the end are datable. In addition, he mentioned that stable and functional conditions were degraded and this imbalance could not be re-established with conventional means. Change, break and continuity should be subsumed under the term crisis. The society is involved and a transformation process must be tangible. Vierhaus additionally argued that a process as a historical crisis goes hand in hand with a subjective sense of crisis. ${ }^{14}$ Jan Marco Sawilla outlined recently that the term crisis functioned perfectly for historians to classify transformation processes in a chronological order or as a phase model and the crisis concept helps to identify events as deviation from the norm. ${ }^{15}$ The following explanations will use the crisis concept as a characterization of the war as a form of upheaval, which caused various changes and modifications regarding the personnel policy of the Habsburg Monarchy during and after the war. We will take a look at how the changing circumstances influenced the personnel recruiting and restructuring processes, the central operation fields of the officials and last but not least we will present selected examples of both professional and unlawful conduct from subaltern and highly ranked personnel.

Establishing a loyal, trustworthy and professional administrative body was of crucial importance from the beginning of the Habsburg rule as an efficiently functioning bureaucracy based on a loyal officialdom had stabilizing effects and acted as an instrument of control. An event of war has serious consequences for all population groups and comprises multifaceted dangers. As an accompanying peril of the Austro-Russian-Turkish War, the Banat was confronted with an outbreak of the bubonic plague. The disease was brought in the second year of the war with the infantry regiment Grünne into the Banat in early 1738. The regiment came from Wallachia. In January the Commander of the Fortress Generalfeldwachtmeister Franz Anton Leopold Ponz Freiherr von Engelshofen (1692-

\footnotetext{
${ }^{11}$ Kallbrunner 1958: 38-74.

12 Steiner 2014; Beer and Dahlmann 1999.

${ }^{13}$ Starn 1971: 3-22; Scholten 2007; Mergel 2011; Schlögl, Hoffmann-Rehnitz and Wiebel 2016; Koselleck 1982 : 617-650.

${ }^{14}$ Vierhaus 1978: 320-322.

${ }^{15}$ Sawilla 2013: 148-149, 167.
} 
$1761)^{16}$ informed his colleagues of the Landesadministration about the disease spread in Transylvania and Wallachia. In February the first outbreak of the bubonic plague in the fortress Temeswar, where the regiment Grünne was stationed, was documented. The disease cost the lives of many people until it was stopped in $1740 .{ }^{17}$ The nexus of the war and the epidemics did not provide conditions for a secure life in the region. But also before that, the Banat had no reputation for being secure and safe. Especially the climatic circumstances and its remoteness classified the region as unattractive. Just like the inhabitants, the officials, who were often newcomers from other parts of the monarchy, were frightened about the unstable situation in the region. While the military parts of the Banatean bureaucracy had war experience, for some civil servants this was a new situation. It should be noted that in the first half of the $18^{\text {th }}$ century civil servants were often in military service before they undertook administrative duties.

\section{Personnel Management during the war}

The following explanation deals with the scope of duties which were conducted by the imperial personnel during the war. The discussed topics illustrate several facets of the supporting activities from single officials as well as the superior process controlling of the administration by the central bodies in Vienna. Finally, strategies of staff recruitment and replacement will be exemplarily discussed.

\subsection{Supporting measurements and supplies management}

By imperial rescripts the Landesadministration was instructed to take the necessary precautions to ensure passage and sufficient supply of the Austrian troops on the territory of the Banat of Temeswar. The civil parts of the Landesadministration were required to undertake tasks under military premises. Josef Wolf outlined that in times of war the Aulic War Council was the source of power regard provincial policy, while in times of peace the balance of power was shared fairly between the Aulic War Council and the Court Camber. The exercising influence derived above all from the political power relations within the central authorities in Vienna. ${ }^{18}$ As the Landesadministration was managed by the General Commander as president the predominance of the military was structurally given until the profound reorganization 1751/53, when the mixed Landesadministration was replaced by a purely civil one. The most important function of the administrative body of the Banat during the war was to organize army provisioning, which involved obtaining, storing, delivering and distributing the victuals necessary to support army operations.

The Aulic War Council estimated the daily supply need of the main army for the campaign 1737 with 138,124 mouth portions ${ }^{19}$ and 67,176 horse portions ${ }^{20}$ of oat.

\footnotetext{
${ }^{16}$ Engelshofen was active in the Banat from 1717 until 1757.

${ }^{17}$ Hammer 1839: 1-2.

18 Wolf 2007: 15.

${ }^{19}$ Mundportion (mouth portion) means a substantial provision of bread, meat and beverages.

${ }^{20}$ Pferdportion (fodder ration) means hay, straw and oat for horses.
} 
Provisions magazines were established in Croatia, Hungary and the Banat. ${ }^{21}$ The imperial troop strength for the war amounted to 216 squadrons, 75 battalions and 59 grenadier companies with 52,900 men and 43,726 horses trooping together in Zemun, Uj-Palanka, Gradiška and Transylvania. Field marshal Friedrich Heinrich von Seckendorf (1673-1763) was appointed as Commander-in-chief. ${ }^{22}$ The Obristproviantamt was independent from the Aulic War Council and responsible for storing food supplies in fortresses and magazines. Rather the Obristproviantamt reported to the Generalkriegskommissariat as supervisory body and the Court Chamber. ${ }^{23}$ Since the conquest of the Banat an own position also referred to as Proviantoffizier, Kasernen- und Proviantverwalter or Provinzialkommissar was created to manage provisions and accommodation in the Banat. ${ }^{24}$ Already on 7 February 1737 the Court Chamber informed the Landesadministration that 4,000 draft oxen were on the way into the Banat and the administration had to provide grasslands for them; in March another 2,000 oxen for the Feldproviantfuhrwesen followed. ${ }^{25}$ On 3 July 1737 the Court Chamber instructed the Landesadministration to produce 30,000 centner hay and 10,000 centner flour. ${ }^{26}$ In addition a high quantity of grain had to be provided and sold to the army. Besides food supply the administrative units were requested to produce war material like ammunition, which was implemented in the mining centers. ${ }^{27}$ All these measures were burdensome for the local population and had to be organized by the personnel in the subordinate departments in the districts (Distriktverwalterämter) with help of Oberknesen and Knesen ${ }^{28}$ on the order of the administration in Temeswar. Mostly with circular resolutions the personnel in the province was instructed in detail and controlled by the authority in Temeswar. ${ }^{29}$ The Landesadministration received instructions by both main authorities in Vienna, the Court Chamber and the Aulic War Council and in cases of urgency directly by the Commander-in-chief of the army. ${ }^{30}$ Provinzialkommissar Wenzel Wilhelm Rössler, who was responsible for organizing the transport of the military and their baggage (Vorspann), mentioned in a letter in July 1737 to the Landesadministration that he wished to withdraw from his charge because the population threaten to hang him. To calm the anger of the population the Landesadministration instructed Rössler to replace the locals burdened with the Vorspann regularly. ${ }^{31}$

\footnotetext{
${ }^{21}$ Angeli 1881: 275.

${ }^{22}$ Angeli 1881: 275-279.

${ }^{23}$ Lindquist 2007: 16-17.

${ }^{24}$ See the Status Personalis of the year 1727 OeStA FHKA NHK ABA 5, January 1728, fol. 128r - 151v; the year 1738 OeStA FHKA NHK ABA 9, May 1738; fol 268r-281r+284r; the year 1739 OeStA FHKA NHK ABA 9, August 1739, fol. 1038v-1090v, 1118v-1124v and the year 1740 OeStA FHKA AHK HF U VUG 30 B, fol. 930r, 944r-945v, 954r-966r, 971r-982r.

${ }^{25}$ Baróti 1893-1896: 35-36.

${ }^{26}$ Baróti 1893-1896: 37.

${ }^{27}$ Baróti 1893-1896: 38.

${ }^{28}$ Oberknesen and Knesen were officials with the duty to order their assigned village or county.

${ }^{29}$ Like the 21 points extensive letter regarding the preparation for the winter quarters in October 1739 after the end of war from the Landesadministration sent to the Distriktsverwalteramt in Orşova. See MOL, E303, 10cs, Ei, fol. $3 r-8 r$.

${ }^{30}$ For instance Baróti 1900-1904: 372.

${ }^{31}$ Baróti 1900-1904: 374-375.
} 


\subsection{Special tasks for selected officials}

The illustrated supporting role of the administrative personnel was extended with special orders for officials. Most of those duties were addressed to and executed by highly ranked officials of the local administration. The previously mentioned Administrative Council Johann Anton de Jean von Hansen fulfilled this position since 1733. On 24 March 1738 the Aulic Sanitary Commission (Sanitätshofkommission) in Vienna decided that the Landesadministration should recommended a capable official who could be responsible for the medical service linked with plague prevention in the Banat. ${ }^{32}$ The spread of plague impeded the effectiveness of the Habsburgs army enormously. It seems that the first choice for the Directorii Sanitatis in Temeswar was the second civil Administrative Council Johann Jakob Benedikt von Neffzer (1705-1785), ${ }^{33}$ but he was soon replaced in July 1738 by de Jean von Hansen with the assistance from the leading accountant in Temeswar Georg Wilhelm Hagen. ${ }^{34}$ Diverse reports addressed to the Aulic Sanitary Commission in Vienna illustrate the duties of de Jean von Hansen, which included the cost management considering the contagion, employment of plague surgeons and physicians, overview of the course of the epidemic and the number of deaths or the transposition and effective implementation of various directives from the sanitary authority in Vienna like the compliance of quarantine and maintenance of quarantine stations. ${ }^{35}$ The plague or trinity memorial in the middle of the cathedral square (Piața Unirii) commemorates the bubonic plague in the Banat and its donor de Jean von Hansen, who commissioned the memorial. Manufactured in Vienna, the memorial was consecrated on 21 November 1740 in Temeswar. ${ }^{36}$

Another official with special tasks was Count Wilhelm Reinhard von Neipperg (16841774). Neipperg had in-depth experience with the region, when he was installed as General Commander of the Banat in winter 1737/38. Neipperg participated in the Turkish-Austrian War 1716/18 and was involved in the frontier revision between the newly defined Habsburg and Ottoman territories after the Treaty of Passarowitz. ${ }^{37}$ Although the Habsburg army achieved some victories in 1737 like the conquest of Niš, which was lost again, in summary the Habsburg campaigns could not evaluated as successful. After the encounter of Grocka on 21-22 July 1739 the Turks were in a victorious position and besieged Belgrade. ${ }^{38}$ As Selim Güngörürler outlined, it seems obvious that the troop strength and military clout of the Ottoman Empire was, especially after the Ottoman-Persian War (1730-1735), underestimated by both of its allied enemies Russia and Austria. ${ }^{39}$ The seriously undervalued but successful army brought the Ottomans in a better bargaining position for

\footnotetext{
32 OeStA KA MilKom Sanitätshofkommission Bücher 1, 1606-1752, March 1738, No.1.

${ }^{33}$ Neffzer was Administrative Council from 1731-1740 in the Banat. Together with Samuel Rebentisch he leased the customs duties in the Banat in 1730.

${ }^{34}$ OeStA KA MilKom Sanitätshofkommission Bücher 1, 1606-1752, July 1738, No. 5.

35 OeStA FHKA NHK Kaale U SanA 2, Sanitätsakten 1738.

${ }^{36}$ Diplich 1972: 103-112.

${ }^{37}$ Neipperg joined the army in 1704. He functioned afterwards as educator of Franz Stephan von Lothringen.

${ }^{38}$ The last war year 1739 is outlined by Angeli 1881: 442-479.

${ }^{39}$ Güngörürler 2014: 99-113.
} 
future peace negotiations. Neipperg was selected to conduct the negotiations. While former negotiations failed, this attempt was brought to an unlucky close for the Habsburg Monarchy. Equipped with comprehensive rights, including the power to surrender the besieged fortress Belgrade as a last resort that would lead to the peace treaty, Neipperg went to the Ottomans' camp, where he was held captive for eleven days. ${ }^{40}$ Personal differences among some of the leading military representatives further ensured the Habsburgs' defeat and finally inadequate communication about the state of war induced Neipperg to sign the peace regulations requested by the Ottomans on 1 September $1739 .{ }^{41}$ The preliminary peace meant the loss of the Austrian parts of Lesser Wallachia, Serbia and Bosnia and was formally confirmed by Emperor Charles VI on 18 September 1739. ${ }^{42}$

Apart from these high ranking officials the subordinate personnel were integrated and used for special services and missions. In 1737 the Oriental interpreter Josef Peter von Schwachheim (1707-1775) ${ }^{43}$ was urgently needed ${ }^{44}$ and Distriktsgegenschreiber ${ }^{45}$ Joseph Hancke (1709-1768) from Lugoj escorted the transport of Spanish orphans across the river Tisza to Kecskemét in Hungary. ${ }^{46}$

\subsection{Employment restructuring and replacement}

While reviewing relevant documents the question that needs to be asked is how the authorities coped and organized employment reconstructions in this uncertain transition phase. The threat of Ottoman troops caused a mass escape of the population. Several imperial officials lost their lives or fled from both the approaching enemy and the spreading disease. In addition to that, a peasant uprising among the Wallachian population created confusion among the people. ${ }^{47}$ The majority of staff recruitments in this phase were based on the concept provisorio modo, which implies that the officials were employed temporarily and provisionally, without a formal imperial decree (Intimationsdekret) from the authorities in Vienna. ${ }^{48}$ Binding appointments were supposed to be fixed after the war. ${ }^{49}$ The above

\footnotetext{
40 Parvev 1995: 233-238; Zedinger 2008: 97-99.

${ }^{41}$ Regele 1954: 373-398.

42 Tupetz 1878: 1-51; Roider 1972: 195-207.

${ }^{43}$ Joseph Peter Schwachheim replaced interpreter de Sain in Orşova in 1734. A letter from the Universalbankalität to the Landesadministration of 11 September 1734. See MOL, E303, 3cs, A, 1734, fol. 84r. Schwachheim became Internuntius (Austrian envoy) in Istanbul in 1754.

${ }^{44}$ Baróti 1900-1904: 375, 378.

${ }^{45}$ Civil servant appointed in the district and financial specialist.

${ }^{46}$ Regarding Spanish families in the Banat see Steiner 2014: 231-243; These Spanish families were settled in 1736. Letter of the Universalbankalität to Landesadministration, 7 July 1736. See MOL, E303, 3cs, A, 1736, fol. 303rv; Letter of the Universalbankalität to the Landesadministration, 8 September 1736. See MOL, E303, 3cs, A, 1736, fol. 340rv and a letter from the Court Chamber to the Landesadministration regard the transport of orphans to Kecskemét see MOL, E303, 4cs, A, 1739, fol. 225rv.

${ }^{47}$ Calincof 1985: 221-241; Feneşan 1973: 165-186.

${ }^{48}$ Like the employment of Egydy Georg Wuntscher as Mautoberdirektionskanzlist. See FHKA NHK ABA 9, January 1738, fol. 7r; regarding the employment of Johann Georg Unger as Kassaverwalter and Maxentius Ströber as Kassakontrollor in Temeswar see OeStA FHKA NHK ABA 9, April 1739, fol. 821r.

${ }^{49}$ For example the discussion about the replacement of the Oberverwalter Wellezky with administrator Bucquay in April 1737 is documented by Baróti 1900-1904: 346.
} 
mentioned Provinzialkommissar Wenzel Wilhelm Rössler was promoted in February 1739 as Oberproviantkommissar and henceforth responsible for the Feldfuhrproviantwesen in Hungary. But formally he retained his job in the Banat and he was planned to fill this position only provisionally during Rösslers' absence until his return. ${ }^{50}$ The applied procedures and practices did not comply with the regular modus operandi regarding the recruitment procedure of low-level civil officials. Normally a formal application to the Court Chamber and a proposal of the Landesadministration, which included three recommended names of officials, were necessary before the authorities in Vienna came to a decision. ${ }^{51}$

Among the high level officials, who constituted the leading presidium, a personnel change had to be done. General Commander and Governor of the Banat Count Johann Andreas von Hamilton (1679-1738) had been replaced. Serious illness made this change necessary. ${ }^{52}$ This restructuring raised several questions under the bureau members. Following the death of Hamilton on 9 January 1738 Engelshofen framed the question: How can the hierarchy be structured, when he, as a newly instructed interim president - on the basis of the exercised seniority principle - would be absent? ${ }^{53}$ The Court Chamber remembered that in this case the other members of the presidium were responsible and in exigent circumstance the Court Chamber should be contacted. ${ }^{54}$ Engelshofens' question became less important with the employment of Neipperg as Hamiltons' successor. The decision was taken to the Aulic War Council and reported by the Court Chamber to Emperor Charles VI, who confirmed the nomination of Neipperg. The Court Chamber emphasized the joint decision-making and did not have any objections regarding this replacement. ${ }^{.55}$

In addition, the presidium was enlarged by another civil Administrative Council in May 1739. This key position was fulfilled with Joseph Viechter Freiherr von Grueb, ${ }^{56}$ who was formerly employed in Lesser Wallachia. The position was planned as a temporary replacement for Neffzer, who was absent on the grounds of health. But when de Jean von Hansens' application for leave to Bratislava was granted, both civil Administrative Councils would have been absent and this caused a suddenly staff shortage. ${ }^{57}$ The problem was solved in a sufficiently simple way, while de Jean von Hansen got the permission to leave (Reiselizenz) if Viechter would arrive in Temeswar. ${ }^{58}$

\footnotetext{
${ }^{50}$ Letter from the Court Chamber to the Landesadministration, 27 February 1739. See MOL, E303, 4cs, A, 1739, fol. 46rv.

${ }^{51}$ For example, the reappointment of the position as Obereinnehmer in Temeswar 1730. See OeStA FHKA NHK ABA 6, February 1730, fol. 68rv, 81r.

52 Steiner 2014: 141.

${ }^{53}$ Engelshofen to the Court Chamber on 25 January 1738. See OeStA FHKA NHK ABA 9, March 1738, fol. 92rv.

${ }^{54}$ Court Chamber to the Landesadministration on 1 March 1738. See OeStA FHKA NHK ABA 9, March 1738, fol. 91rv.

${ }^{55}$ Undated report of the Court Chamber to Charles VI. See OeStA FHKA NHK ABA 9, February 1738, fol. 65rv, $68 \mathrm{r}$.

${ }^{56}$ Viechter was born in Freiburg/Breisgau and died in Temeswar in 1748.

${ }^{57}$ Letter from the Court Chamber to the Landesadministration on 15 May 1739. See MOL, E303, 4cs, A, 1739, fol. 221rv and the undated report of the Court Chamber to the Emperor OeStA FHKA NHK ABA 9, May 1739, fol. 864rv, 876r.

${ }^{58}$ Letter from the Court Chamber to the Landesadministration on 24 June 1739. See OeStA FHKA NHK ABA 9 ,
} 
As a final point it should be mentioned that cases of staff increase were reported. Neffzer asked in January 1738 if he could employ some scouts or spies, who could be used in the Ottoman Empire to monitor the troop movement activities. ${ }^{59}$ The recruitment of informants was granted, however, but no additional resources were provided. ${ }^{60}$

\section{Personnel Management after the war}

The second part of this paper is dedicated to the post war period. We will take a look at the consequences based on negligent behavior and analyze the handling and processing of staff reconstruction, which was getting mandatory due to death, escape and displacement of employed personnel from the Banat and the bordering provinces Serbia and Oltenia, which were now again ruled by the Ottoman Empire. In connection with the initiated reconstruction measures the duties of selected officials will be investigated.

\subsection{Types of misconduct and punishment}

The military failings during the war resulted in various charges against high ranking military personnel. The fate of the Swiss Nikolaus Doxat de Morez (1682-1738), Field marshal lieutenant and engineer, had a deterrent effect. He was held responsible for the loss of Niš without considerable resistance in the year 1737 and condemned to death by a court martial. Perhaps to make an example of him, he was beheaded after a successful military career in March 1738 in Belgrade. ${ }^{61}$ Field marshal Georg Oliver Graf von Wallis (16731740), as well as his predecessor Seckendorf in 1738, and Neipperg were imprisoned until after the dead of Charles VI. ${ }^{62}$ The investigations concerning misconduct or negligence against Neipperg were stopped per imperial decree of Maria Theresia and he was released from prison completely rehabilitated. ${ }^{63}$ Since September 1739 August Jakob Heinrich Freiherr von Suckow functioned as General Commander and Governor in the Banat. Suckow was the Commander of the Fortress Belgrade from 1738-1739. ${ }^{64}$

While the misconduct of highly ranked personnel was mostly investigated, subordinate staff was mainly spared from legal consequences or punishment. For historians the investigation of this period is difficult because of the lack of material sources. This problem stems from 1738, when Administrative Council Neffzer left Temeswar and took several

\footnotetext{
June 1739, fol. 985r.

${ }^{59}$ Neffzer to the Court Chamber from 8 January 1738. See OeStA FHKA NHK ABA 9, February 1738, fol. 33rv.

${ }^{60}$ Letter from the Court Chamber to the Landesadministration from 1 March 1738. See OeStA FHKA NHK ABA 9, March 1738, fol. 89r.

${ }^{61}$ Samardžić and Abramović 2013: 41-50; Doxat 1954.

62 Hochedlinger 2003: 214-216.

${ }^{63}$ Regele 1954: 385. For additional archival material regard Neipperg and the Peace of Belgrade see OeStA HHStA Kriegsakten 281-1, 1739.

${ }^{64}$ Concerning the new installed Commander Suckow see his Intimationsdecret from 14 September 1739. MOL, E303, 4cs, A, 1739, fol. 318r-319v as well as OeStA FHKA NHK ABA 9, October 1739, fol. 1256r and about the report of his imminent death from the Landesadministration on 16 March 1740 see OeStA FHKA NHK ABA 10, March 1740, fol. 296rv. Suckow died on 12 March 1739 in Temeswar.
} 
files of the Landesadministration with him. ${ }^{65}$ The Court Chamber asked former employees Neffzer and de Jean von Hansen in July 1742 where these documents and other missing files could be. ${ }^{66}$ Ultimately the material was lost. With no further clarifications by Neffzer forthcoming, de Jean von Hansen mentioned that parts of the materials were probably "rotten during transport or destroyed by quarantine measurements" and finally lost in the chaos of war. ${ }^{67}$ The involved personnel ${ }^{68}$ could neither clarify the matter nor were punished for their negligent behavior. Why accounting and file archiving was not at all well organized in the Banat of Temeswar is another chapter. By shrinking the autonomy of the administration and giving them rules and regulations the Court Chamber tried to control their bookkeeping and their finances intensively. ${ }^{69}$ It seems that the unlucky course of war lead to the fact that besides the Wallachian population some low level members of the imperial officialdom were tempted to defect to the enemy. ${ }^{70}$ In this respect, it should be noted that only in a small amount of cases legal action was taken. ${ }^{71}$ On 10 January 1739 a circular decree including a "general pardon" was published with the aim to put down the unrest, prevent robbery and to establish stable conditions for the population and officials. ${ }^{72}$

\subsection{Imperial requirements concerning returnees and new employees}

At the request of Administrative Council Neffzer in October 1737 regarding how displaced and escaped customs officers of the Banat and Lesser Wallachia should be treated, the Court Chamber pointed the way for the future approach regarding the returning officials. It should be noted that the authorities in Vienna could not draw on a preconceived procedure to manage the emerging challenges relating to personnel matters in periods of turbulence. The Court Chamber stipulated that all customs officials who were displaced should receive their outstanding salaries from the date of the escape for the next year. In addition, if those officials came back, they should be employed before others. To gain an overview about escaped customs officers the Court Chamber requested a table including the name, place of work and salary of the employees. ${ }^{73}$ This topic dominated the correspondence between Vienna and Temeswar in the context of personnel management strategies and required an

\footnotetext{
${ }^{65}$ Neffzer went to Ofen because of health problems. See the letter exchange, including a medical certificate OeStA FHKA NHK ABA 9, Aug 1738, fol. 498r-503v, 506r, 514r. The Neoaquistische Subdelegation discussed the problem of the carried files by Neffzer on 27 November 1738. See the protocol of the Subdelegation OeStA FHKA NHK ABA 9, November 1739, fol. 671r-672r.

${ }^{66}$ Requests in July 1742. See OeStA FHKA NHK ABA 12, July 1742, fol. 7r.

${ }^{67}$ Letter from de Jean von Hansen from 10 September 1742 to the Landesadministration. See OeStA FHKA NHK ABA 12, November 1742, fol. 28r-30v.

${ }^{68}$ Registrator Westerheimb, Konzipist Weigant as well as Kassabeamte Ströber and Unger.

${ }^{69}$ See as example about missing invoices or accounting data OeStA FHKA NHK ABA 6, June 1731, fol. 768rv or for later years OeStA FHKA NHK ABA 24, July 1750, fol. 133rv.

${ }^{70}$ Cases about disloyal Knesen and Oberknesen especially in the district of Új-Palánka are documented by reports of Gegenschreiber Stögmann. See Baróti 1900-1904: 27.

${ }^{71}$ For example, some Oberknesen of the District of Lippa for distributing gifts to Ottomans were released from prison in August 1738. Report of the Verwalteramt of Lippa. Baróti 1900-1904: 84-85.

72 Baróti, 1893-1896: 187 as well as Surdu 1957, 319.

${ }^{73}$ Writing of the Court Chamber to Neffzer on 20 December 1737. See OeStA FHKA NHK ABA 7, December 1737, fol. 1771rv.
} 
excellent problem-solving competence of the court. The war exceeded the scope of state finance and the financial resources were in a very poor shape. Nonetheless the court in Vienna tried to pay all outstanding wages. ${ }^{74} \mathrm{~A}$ mandatory regulation for returnees was published on 10 January 1739: The outstanding salaries for personnel who left the Banat without travel license would be paid retroactively until the end of the preceding year 1738 . The Landesadministration received the order to inform those members of the administrative apparatus who were at this point in time not in the Banat to return within five to six weeks. ${ }^{75}$ Upon this request many officials informed the Landesadministration about their swift return. ${ }^{76}$ Some of these writings included an application for a travel allowance, which was granted in most cases as a form of advance. This regulation included religious personnel as well, such as the return of two catholic priests, named Franz de Boison and Johann Georg Spindler. Both got $75 \mathrm{fl} .{ }^{77}$ for two outstanding quarters ${ }^{78}$ of their Stipendy and $75 \mathrm{fl}$. as travel advance to come back to the Banat. ${ }^{79}$ To strengthen the Catholic faith in the Banat the salaries of priests were paid of course by the state. The Bishop of Csanád, Eusebius Anton Adalbert Freiherr von Falckenstein (1661-1739), ${ }^{80}$ described colorfully the dreary life of his priests in the Banat and expressed his concern that without financial allowance further priest would leave. As a consequence, the Court Chamber instructed the Landesadministration in April 1739 to pay one quarter of the outstanding ecclesiastical salaries in the Banat immediately. ${ }^{81}$

In-depth explanations of the regulation from 10 January were outlined in a letter of the Court Chamber to the Landesadministration in March 1739. Firstly, all returning officials needed a formal legitimation from the Court Chamber and, secondly, returnees would hold the privilege for their former job if substitute personnel was recruited in the meantime. ${ }^{82}$ The official who were temporarily employed were supposed to employed elsewherein the

\footnotetext{
${ }^{74}$ The Landesadministration informed the Court Chamber on 21 May 1738 about the bad financial situation and that the proposed finance system for 1738 could not implemented regarding the war and bubonic plague. See OeStA FHKA NHK ABA 9, July 1738, fol. 470rv.

${ }^{75}$ Instruction from the Court Chamber to the Landesadministration, 10 January 1739. See OeStA FHKA NHK ABA 9, January 1739, fol. 701rv, 704r.

${ }^{76}$ As an example the Distriktamtschreiber in Lugoj Johann Kaspar Perl. He got his outstanding salary for two quarters 45 fl. Instruction to the Universalbankalität from 5 February 1739. See MOL, E303, 4cs, A, 1739, fol. 35r; regarding the advance the letter of the Universalbankalität to the Landesadministration from 21 February 1739. See MOL, E303, 4cs, A, 1739, fol. 67r.

$77 \mathrm{fl}$. means gulden.

${ }^{78}$ Salaries were paid quarterly.

79 Regarding the outstanding ecclesiastical salaries, the letter from the Universalbankalität to the Landesadministration from 20 May 1739. MOL, E303, 4cs, A, 1739, fol. 227rv and about their travel advance the letter from the Court Chamber to the Landesadministration from 15 October 1739. See MOL, E303, 4cs, A, 1739, fol. 340rv.

80 After the death of Bishop Ladislaus Graf von Nádasdy (1662-1729), Falkenstein got this position on the recommendation of Eugen von Savoyen in 1730. In 1731 followed the pontifical confirmation and in 1732 he arrived in Temeswar.

${ }^{81}$ The outstanding quarter had to be paid from the resources of salt mining in Szeged. Letter from the Court Chamber to the Landesadministration from 14 April 1739. See MOL, E303, 4cs, A, 1739, fol. 159r-160v.

${ }^{82}$ Instruction from the Court Chamber to the Landesadministration from 21 March 1739. See OeStA FHKA NHK ABA 9, March 1739, fol. 809rv.
} 
empire according to their preference when the original staff returned to the Banat. This primarily affected personnel from Serbia and Lesser Wallachia, who lost their jobs due to the military confrontations. In June 1739 the regulation was intensified by the amendment that only personnel who had been in imperial service for a while and especially expelled imperial officials should be appointed. ${ }^{83}$ The recruitment of Benedikt von Kirchstetter should serve as example for the appointment of personnel who had previously been part of the administrative apparatus of Belgrade. The letter of application from Kirchstetter ${ }^{84}$ comprised several personal details which offer us a brief insight into the life circumstances of him and his family. Kirchstetter was married and had five children when he lost his job as Salzwaagmeister ${ }^{85}$ in Gradiška. At that time, he was deployed for 16 years in military and 20 years in civil service. Kirchstetter referred to his relatives, who were also employed in imperial service with proven loyalty to the Emperor. Kirchstetter asked for a new job and heretofore financial support, which meant continuing to draw his salary of $300 \mathrm{fl}$. for a year. ${ }^{86}$ The Court Chamber decided to employ Kirchstetter as of 1 January 1740 because of his documented faithfully performed services for the state and his experience as Salzeinnehmer ${ }^{87}$ in Temeswar. $^{88}$ In November 1739 the Court Chamber pointed out repeatedly that only officials who were in imperial service should be engaged. At the same time the Court Chamber demanded an overview of the body of officials in the Banat and stipulated that without formal approval issued by the authorities in Vienna the salaries of the affected personnel would be suspended. ${ }^{89}$

To always have an overview of the number of employees, the need for restructuring, the organization of new recruitments or employees' departures of service, the Landesadministration was obligated to send in an annual Status Personalis in advance. After an evaluation by the Neoaquistischen Hofkommission the proposal was implemented or critical points improved. This state mechanism of control offers the possibilities to control the functioning of the Landesadministration in personnel matters. A representative list of all civil officials was made in the style of a Status Personalis with the status of the year 1739. This list comprised four categories based on their annual salaries: personnel presently in the Banat, personnel who left the Banat with a travel license, personnel who left the Banat without a travel license and personnel with a suspended salary. The positions were listed with the name of the official linked with his professional title, which included the information about his place of work directly in Temeswar or in the districts. The clergy was also included. ${ }^{90}$ It should be emphasized that with 10,358 fl. just under one quarter of

\footnotetext{
${ }^{83}$ The instruction was defined accurately in the course of a new hire at the customs office in Nagykanizsa. Court Chamber to the Landesadministration on 10 June 1739. See OeStA FHKA NHK ABA 9, June 1739, fol. $916 \mathrm{r}$.

${ }^{84}$ Sometimes the name was written either as Kirchstätter or Kirchstettner.

${ }^{85}$ Responsible for measure of the weight of salt.

${ }^{86}$ Undated letter of application from Kirchstetter. See OeStA FHKA NHK ABA 9, October 1739, fol. 1278r-1279r.

${ }^{87}$ Responsible for the administration of revenues regarding salt mining.

${ }^{88}$ Letter from the Court Chamber addressed to the Landesadministration from 30 October 1739. See OeStA FHKA NHK ABA 9, October 1739, fol. 1277rv. Upon his own request he got a salary supplement of 150fl in January 1741, limited to three years. See OeStA FHKA NHK ABA 11, January 1741, fol. 44r.

${ }^{89}$ Court Chamber to the Landesadministration on 20 November 1739. See OeStA FHKA NHK ABA 9, November 1739, fol. 1292r.

${ }^{90}$ Excluded were officials from customs, mining and salt mining.
} 
the estimated annual salaries of 39,544 fl. were classified as suspended in this phase. Most of the reasons for this are based on internal reorganizations caused by displacement, death, the lack of formal legitimation or staff savings due to the war. ${ }^{91}$ In 1740 the situation became more stable and the most posts (especially in the districts) were be filled again. ${ }^{92}$

\subsection{Personnel policy in the light of reconstruction and reorganization}

After the war crucial observations were initiated in Vienna to reorganize the administrative structure in the Banat. Upon a resolution of the Staatskonferenz from 17 March 1740 a distinct Hofkommission led by Hofkammerrat ${ }^{93}$ Ferdinand Alois Count von Kolowrat (1682-1751) was installed to analyze the structural conception of the administration in the Banat. ${ }^{94}$ From a personnel policy perspective the commission tried to superficially reform the division of competences between civil and military staff. The priority topic was to install a civil governor of the Banat. Furthermore, the improvement of administrative structure, internal processes and communication linked with the responsible personnel were part of the controversial discussion between the involved Hofkammerräte and Hofkriegsratsräte. ${ }^{95}$ The commission consulted the experienced Banat Administrative Councils de Jean von Hansen and Ignaz Dismas Kempf von Angret ${ }^{96}$ as well as Engelshofen. ${ }^{97}$ Written expert opinions were drafted by Neffzer and Kempf (1704-1768), ${ }^{98}$ but in the end no significant changes were initiated and implemented.

The unlucky peace agreement requested a renewed border demarcation. Engelshofen was instructed to form his own commission. Article 5 of the Treaty of Belgrade raises some uncertainties and as Francesco Griselini remarked, the Ottoman and Austrian engineers decided that the river Cerna had to be redirected around Orşova (Alt-Orsova) with help of a newly constructed canal into the Danube. Finally, the Ottomans were not able to complete the construction works within the estimated time (18 September 1740), which meant that some villages, including the hot-springs of Mehadia, stayed under the Habsburg rule. ${ }^{99}$

On 27 February 1740 the Aulic War Council mentioned in a letter to the Court Chamber that commissioner Engelshofen needed to start with the financial project

\footnotetext{
${ }^{91}$ See MOL, E303, 4cs, A, 1739, fol. 272v-285r and OeStA FHKA NHK ABA 9, Aug 1739, fol. 1083v-1090r, $1118 \mathrm{v}-1124 \mathrm{v}$.

${ }^{92}$ Status Personalis of the year 1740. See OeStA FHKA AHK HF U VUG 30 B, fol. 930r, 944r-945v, 954r-966r, 971r-982r.

${ }^{93}$ Council of the Court Chamber.

94 The experts dealt with those five topics: Cultus Divinus and religion, governmental charges, judicial administration, personnel composition of the Landesadministration and military security. For details see Kallbrunner, Banat, 84-90 or an undated report by the commission OeStA FHKA NHK Banater Akten 66, fol. $555 \mathrm{v}-557 \mathrm{v}, 570 \mathrm{v}-586 \mathrm{r}$.

${ }^{95}$ Councils of the Court Chamber and the Aulic War Council.

${ }^{96}$ Kempf von Angret was employed as inspector at the Banater Landesadministration between1731-1734. Since 1734 he was Administrative Council in Belgrade.

${ }^{97}$ Meeting protocol 29 April 1740. See OeStA FHKA NHK Banater Akten 66, fol. 470r-471r.

${ }^{98}$ Kallbrunner 1958: 85.

${ }^{99}$ Griselini 1780: 175 and Vaníček 1875: 473-475.
} 
subsidies. A supplement list respective some gifts for the Ottoman officials was attached. ${ }^{100}$ After a report of the Court Chamber to the Emperor Engelshofen should have got the proposed 2,000 ducats in March 1740. ${ }^{101}$ Engelshofen started the commission on 5 March 1740 and successfully completed the commission in May 1741. All in all, they needed 13 months including a winter break. ${ }^{102}$ After the war the Habsburg Monarchy found themselves in enormous financial troubles, which was reflected in providing adequate funding for the commission of Engelshofen. As a result, very soon the first claims about outstanding travel expense allowances (Liefergelder) were transmitted to the Aulic War Council. Interpreter Joseph Peter von Schwachheim demanded for the period from 1 March 1740 until 16 May 1740, i.e. for 77 days, a sum of $385 \mathrm{fl}$. (5 fl. per day). ${ }^{103}$ Similarly, Engelshofen was not paid the aforementioned 2,000 ducats nor any travel expense allowance until July $1740 .{ }^{104}$ In August 1741 parts of the expenses of the involved military personnel ${ }^{105}$ for the border demarcation were unpaid, which was finally settled with a flat fee of $6,000 \mathrm{fl}^{106} \mathrm{~A}$ temporary member of the commission was Feldkriegskanzlist Johann Florian Weigant (1711-1752). He was employed at the Landesadministration in Temeswar and with the support of Administrative Council Viechter the payment of his claims was initiated in June $1741 .{ }^{107}$ It required a little time until the necessarily advance-money was refunded. Besides this specialized staff, personnel of the districts were used equally to support the commission. ${ }^{108}$

After the war, the industry was in tatters. The mining sector, which was classified as exceptionally profitable, was disproportionately affected as a consequence of the Wallachian peasant uprising and the Ottoman lootings in the mining areas. In 1736 the business was already organized by unions until the war. ${ }^{109}$ The mining sector was supposed to be reorganized under the leadership of Bartholomäus Ludwig Hechengartner

${ }^{100}$ Letter of the Aulic War Council to the Court Chamber from 27 February 1740. See OeStA FHKA NHK ABA 10, March 1740, fol. 268r-270r.

${ }^{101}$ Report of the Court Chamber from 10 March 1740. See OeStA FHKA NHK ABA 10, March 1740, fol. 266r-267r. Instruction to the Universalbankalität from 10 March 1740. See OeStA FHKA NHK ABA 10, March 1740, fol. 265r.

${ }^{102}$ Report from the Landesadministration to the Court Chamber from 16 March 1740. See OeStA FHKA NHK ABA 10, March 1740, fol. 296rv and FHKA NHK ABA 11, August 1741, fol. 4r-5v.

${ }_{103}$ Writing of the Aulic War Council to the Court Chamber from 13 September 1740. See OeStA FHKA NHK ABA 10, October 1740, fol. 886rv.

${ }^{104}$ Reminder from the Aulic War Council to the Court Chamber from 28 July 1740. See OeStA FHKA NHK ABA 10, December 1740, fol. 1047rv.

105 The listed military personnel comprised of Engelshofen, interpreter Schmidt, Kriegskanzlist and Konzipient Miethe, Kriegskanzlist Cunz, engineer Kayser and engineer Bembler. See OeStA FHKA NHK ABA 11, August 1741, fol. $4 \mathrm{r}-5 \mathrm{v}$.

${ }^{106}$ Instruction of the Court Chamber to the Universalbankalität from 5 August 1741. See OeStA FHKA NHK ABA 11, August 1741, fol. 3r.

${ }^{107}$ Note exchange including a personal letter of Weigant and Viechter. See OeStA FHKA NHK ABA 11, June 1741, fol. $62 \mathrm{r}-66 \mathrm{v}$.

${ }^{108}$ Such as the district administrator in Caransebeș, named Plasch and his Gegenschreiber Morgner in May 1741. Baróti 1900-1904: 199-200.

${ }^{109}$ Wessely 1937: 55-60. 
(1702-1773). ${ }^{110}$ During the war Hechengartner commanded the so-called Bergschützenkompagnie. This company was installed to prevent attacks especially in the mining area of Majdanpek. On 2 April 1740 the Court Chamber informed the Landesadministration that Oberbergmeister and Bergrat Hechengartner received the instruction to reconstruct the mining in the Banat. Similarly the Universalbankalität informed Administrative Council Viechter that a one off payment of 3,000 fl. giving the economy a boost as well as $150 \mathrm{fl}$. travel expense allowances per month should be provided for Hechengartner. ${ }^{111}$ For example, Hechengartner organized the construction of buildings and accommodation for the mining personnel as a report from 7 August 1740 documented. It was addressed to the Landesadministration and written in Oravița. ${ }^{112}$ It seems that the mining business was not as profitable as desired and the Court Chamber decided to outsource the mining business segment again from the imperial responsibility into the responsibility of a union, which reduced both personnel costs and the financial risk, which was enormous for the state. ${ }^{113}$

\section{Conclusion}

From an administrative point of view an event of war represents an enormous challenge to the state. All personnel capacities have to be utilized for war purposes and administering a provincial region, which was directly affected by war, became more complex. The involved personnel were confronted with more new tasks, which had to be implemented efficiently for the best interest of the state. Crisis management became a keyword for those processes. The Banat of Temeswar provided staff as well as natural resources, which was not always easy to accomplish for the war-ravaged province. The status of the Banat as a crown and chamber demesne was responsible for the circumstance which entitled the authorities in Vienna to have complete access to personnel and economic resources of the province. In particular, the lack of regional estates made this unrestricted imperial access possible. During the war the main duties were focused on the supplies for the army. The administrative personnel across all hierarchies were used in this way. This layoff of personnel was not instructed as an extraordinary measure. It was rather taken for granted. The death toll linked to the bubonic plague and war led unavoidably to restructuring measurements, which could be seen mostly as provisional solutions with the character of improvisation. High staff turnover accompanied this processes, which lead to the loss of overview and control over the employed personnel in the Banat and made the repeated

\footnotetext{
${ }^{110}$ Hechengartner came to the Banat with his father during the 1720s. He worked in Majdanpek. In 1733/1734 he was Bergmeister in Czernestiza, which was merged with Majdanpek in 1736. It seems that he changed his name from Hechengartner to Hechengarten. He became Oberbergmeister and inspector of the Banat regarding mining and 1747 k.k. Bergrat. On 14 November 1749 Hechengarten was ennobled and received the name affix Edler von. For details see Lacko 2014: 162-199.

${ }^{111}$ Baróti 1893-1896: 51-52. For his commitment in the Banat he got $800 \mathrm{fl}$ a year. Writing of the Court Chamber to the Universalbankalität from 2 April 1740. See OeStA FHKA NHK ABA 10, April 1740, fol. 298rv.

${ }^{112}$ Hechengartner to the Landesadministration from August 7, 1740. SJAN Timiş, DMD, Fond 130, 1740-9, fol. $1 \mathrm{r}-2 \mathrm{r}$.

${ }^{113}$ Hofkammerdekret 1834: 41-43; Fülepp and Marquardt 1848: 7-18.
} 
requirement of personnel data by the authorities in Vienna necessary. It must be considered that the Banat of Temeswar was not the only crisis region at this time and the Habsburg Empire was faced with new military challenges after the Austro-Russian-Turkish War. The subsequent War of the Austrian Succession (1740-1748) bound many resources and with that, a new theatre of war emerged which hampered the executive control of the authorities in Vienna. Especially in the year 1739 the Viennese court decreed regulations with social dimensions. Facets of state welfare towards employees were tangible. This was triggered by a sum of applications for financial support or new jobs, especially from officials of Serbia and Wallachia, which reached the Viennese court. It seems that the initiated measures should ensure the integration of these personnel who lost their livelihood in the bureaucratic machine of the Banat without any fault on their part. In this way a contribution to support these officials and their relatives could be made efficiently. In addition, the Landesadministration relied on these personnel, while many officials who were killed in the war became victims of the bubonic plague or fled from the Banat. A deep uncertainty caused by the events in this transition phase affected the officials and the population in various ways. The daily routine of their personal and working life was harshly interrupted and valid concerns and fears accompanied their everyday life during the years of war. Some of them lost their relatives, jobs or property and were forced to carry out a new strategy to start their lives again after the chaotic circumstances subsided. To stabilize the region sufficient personnel was necessary. It is not surprising that the Court Chamber more or less willingly paid outstanding salaries and granted travel allowances in advance for returnees, even though the treasury was empty and the financial resources had been exhausted. The court was aware that these officials and their loyalty were absolutely needed during the period of reconstruction. With the unfortunate end of the war, the Banat of Temeswar received a new position within the body of the Habsburg Monarchy because with the Treaty of Belgrade the Banat became a border region and questions concerning defense and security moved into the center of attention, which expanded the range of duties of civil and military personnel in the Banat in another way.

\section{REFERENCES:}

Archival sources:

National Archives of Austria:

OeStA FHKA NHK ABA - Österreichisches Staatsarchiv, Finanz- und Hofkammerarchiv, Neue Hofkammer, Ältere Banater Akten

OeStA FHKA AHK HF U VUG - Österreichisches Staatsarchiv, Finanz- und Hofkammerarchiv, Alte Hofkammer, Hoffinanz Ungarn, Vermischte Ungarische Gegenstände

OeStA FHKA NHK Kaale U SanA - Österreichisches Staatsarchiv, Finanz- und Hofkammerarchiv, Neue Hofkammer, Kamerale Ungarn, Sanitätsakten

OeStA KA MilKom Sanitätshofkommission Bücher - Österreichisches Staatsarchiv, Kriegsarchiv, Militärkommando, Sanitätshofkommission Bücher

OeStA HHStA Kriegsakten - Österreichisches Staatsarchiv, Haus-, Hof- und Staatsarchiv, Kriegsakten 
National Archives of Hungary:

MOL E303 - Magyar Országos Levéltár, E303 = Landes Administration in dem Banat Temesvár

References:

Aksan, V. H. Ottoman Wars 1700-1870. An Empire Besieged, London-New York: Routledge 2013.

Angeli, M. 'Der Krieg mit der Pforte 1736 bis 1739', Mittheilungen des k.k. Kriegs-Archivs, 1881, 247-338, 409-479.

Baróti, L. Adattár Délmagyarország XVIII. Századi tőrténetéhez, Vol. I, Timişoara: 1893-1896. . Adattár Délmagyarország XVIII. Századi tőrténetéhez, Vol. II, Timişoara: 1900-1904.

Becker, P. and von Krosigk, R. 'New Perspectives on the History of Buraucratic and Scientific Subjects', in: Becker, P. and von Krosigk, R. (eds.), Figures of Authority. Contribution toward a Cultural History of Governance from the Seventeenth to the Twentieth Century, Bruxelles/Bern/Berlin: Peter Lang, 2008, 11-26.

Beer, M. and Dahlmann, D. Migration nach Ost- und Südosteuropa vom 18. bis zum Beginn des 19. Jahrhunderts, Stuttgart: Jan Thorbecke Verlag, 1999.

Brakensiek, S. 'Neuere Forschungen zur Geschichte der Verwaltung und ihres Personals in den deutschen Staaten 1648-1848', in: Heyen E. V. (eds.), Verwaltungseliten in Westeuropa (19./20. Jh.), Baden-Baden: Nomos Verlagsgesellschaft, 2005, 297-326.

Calincof, E. 'Atestări documentare privind caracterul antihabsburgic al răscoalei populare din Banat în anii 1737-1739', Banatica, 8, 1985, 221-241.

Diplich, H. Die Domkirche in Temeswar. Ein Beitrag zu ihrer Baugeschichte, München: Verlag des Südostdeutschen Kulturwerkes, 1972.

Doxat, R. Nikolaus Doxat. Ein Kaiserlicher General und Ingenieur des XVIII. Jahrhunderts. Dargestellt vor allem an Hand der Quellen des Oesterreichischen Kriegsarchivs zu Wien, Vienna: Diss., 1954.

Feneşan, C. Administrație şi fiscalitate în Banatul imperial (1716-1778), Timişoara: Ed. de Vest, 1997.

. 'Informaţii documentare privind răscoala populară bănățeană de la 1737-1739', Banatica, 2, 1973, 165-185.

Fülepp, A. and Marquardt, F. Geschichte des gewerkschaftlichen Metallbergbaues im Banate, sammt einer kritischen Darstellung der Verwaltung desselben durch die königlichen Montan=Behörden. Vienna: Carl Gerold, 1848.

Griselini, F. Versuch einer politischen und natürlichen Geschichte des temeswarer Banats in Briefen an Standespersonen und Gelehrte, Erster Theil, Vienna: Verlag Johann Paul Krauß, 1780.

Güngörürler, S. The Repercussions of the Austro-Russian-Turkish War (1736-1739) on the Diplomacy and the International Status of the Ottoman Empire, Istanbul: Libra Kitapçllık ve Yayıncılık 2014.

Hochedlinger, M. Austria's Wars of Emergence. War, State and Society in the Habsburg Monarchy 1683-1797, London: Longman, 2003.

'Hofkammerdekret. Organisirung der banatischen Bergwerks=Administration. Wien den 6. Februar 1742', in: Schmidt F. A. (eds.), Chronologisch=systematische Sammlung der Berggesetzte der österreichischen Monarchie. Wien: k.k. Hof= und Staats=Aerarial=Druckerey, 1834, 41-43.

Ingrao, C. W., Samardžić, N., Pesalj, J. The Peace of Passarowitz, West Lafayette: Purdue University Press, 2011.

Jordan, S. Die kaiserliche Wirtschaftspolitik im Banat im 18. Jahrhundert, Munich: Oldenbourg, 1967.

Kallbrunner, J. Das kaiserliche Banat. Einrichtung und Entwicklung des Banats bis 1739, Munich: Verl. d. Südostdt. Kulturwerks, 1958.

'Zur Geschichte der Wirtschaft im Temescher Banat bis zum Ausgang des Siebenjährigen 
Krieges', Südostdeutsche Forschungen, 1, 1936, 46-60.

Koselleck, R., 'Krise', in: Brunner, O., Conze, W. and Koselleck, R. (eds.), Geschichtliche Grundbegriffe. Historisches Lexikon der politisch-sozialen Sprache in Deutschland, 3. Vol., Stuttgart: Klett-Cotta Verlag 1982, 617-650.

Kucsko, I. Die Organisation der Verwaltung im Banat vom Jahre 1717-1738, Vienna: Diss., 1934.

Lacko, M. 'K transferu inovácií v stredoeurópskom hutníctve: Bartolomej Ludovít Hechengartner (1702-1773) a zhutňovanie medi na Spiši v prvej polovici 18. storočia’, Montánna história, 7, 2014, 162-199.

Langer, J. 'Serbien unter der kaiserlichen Regierung 1717-1739', Mittheilungen des $k$. und $k$. Kriegsarchivs, new series, 3, 1889, 155-247.

Lindquist, T. 'Clement von Radolt (1593-1670): 'A Multifarious Career in the seventeenth century Imperial Service’, Mitteilungen des Österreichischen Staatsarchivs, 52, 2007, 9-29.

Mergel, T. (eds.), Krisen verstehen. Historische und kulturwissenschaftliche Annäherungen, Frankfurt am Main: Campus Verlag, 2011.

Mraz, H. Die Einrichtung der kaiserlichen Verwaltung im Banat von Temesvár, Vienna: Diss., 1984.

Papacostea, S. 'Der Absolutismus in den Randgebieten der Habsburgermonarchie. Die Kleine Walachei unter österreichischer Verwaltung 1718-1739', Mitteilungen des Österreichischen Staatsarchivs, 23, 1970, 36-63.

Parvev, I. Habsburgs and ottomans between Vienna and Belgrade (1683-1739), New York: Columbia University Press, 1995.

Petri, A. P. Biographisches Lexikon des Banater Deutschtums, Marquartstein: Breit, 1992.

Regele, O. 'Die Schuld des Grafen Reinhard Wilhelm von Neipperg am Belgrader Frieden 1739 und an der Niederlage bei Mollwitz 1741', Mitteilungen des Österreichischen Staatsarchivs, 7, 1954, 373-398.

Reinhard, W. (eds.), Power Elites and State Building, New York: Oxford University Press, 1996.

Ritter von Stefanovic-Vilovsky, T. Belgrad unter der Regierung Kaiser Karls VI 1717-1739, Vienna: Holzhausen, 1908.

Roider, K. A. Austria's Eastern Question, 1700-1790. Princeton: Princeton University Press, 1982.

. 'The Perils of Eighteenth-Century Peacemaking: Austria and the Treaty of Belgrade, 1739', Central European History, 5, 3, 1972, 195-207.

Samardžić, N. and Abramović, V. 'Švajcarac u Beogradu: Nikola Doksat de Morez'. Limes Plus, 2, 2013, 41-50.

Sawilla, J. M. 'Zwischen Normabweichung und Revolution - 'Krise' in der Geschichtswissenschaft', in: Meyer, C., at al. (eds.), Krisengeschichte(n). "Krise" als Leitbegriff und Erzählmuster in kulturwissenschaftlicher Perspektive, Stuttgart: Franz Steiner Verlag, 2013, 145-172.

Schlögl, R., Hoffmann-Rehnitz, P. R. and Wiebel E. (eds.), Die Krise in der Frühen Neuzeit, Göttingen: Vandenhoeck \& Ruprecht GmbH, 2016.

Scholten, H. (eds.), Die Wahrnehmung von Krisenphänomenen. Fallbeispiele von der Antike bis in die Neuzeit, Köln/Weimar/Vienna: Böhlau, 2007.

Starn, R. 'Historians and Crisis', Past and Present, 52, 1, 1971, 3-22.

Steiner, S. Rückkehr unerwünscht. Deportationen in der Habsburgermonarchie der Frühen Neuzeit und ihr europäischer Kontext, Wien/Köln/Weimar: Böhlau Verlag, 2014.

Surdu, B. 'Răscoala populară habsburgică din Banat (1737-1739)', Studii şi materiale de istorie medie, 2, 1957, 289-344.

Tupetz, T. 'Der Türkenfeldzug von 1739 und der Friede zu Belgrad', Historische Zeitschrift, 40, 1878, $1-51$.

Vaníček, F. Specialgeschichte der Militärgrenze, aus Originalquellen und Quellenwerken geschöpft, Vol. 1, Vienna: k.-k. Hof- und Staatsdruckerei, 1875. 
Vierhaus, R. 'Zum Problem historischer Krisen', in: Faber K.-G. and Meier C. (eds.), Historische Prozesse, Munich: Deutscher Taschenbuch Verlag, 1978, 313-329.

von Hammer, A. Geschichte der Pest, die von 1738 bis 1740 im Temeswarer Banate herrschte, Timișoara: Verlag Joseph Beichel, 1839.

Wendehorst, S. (eds.), Die Anatomie frühneuzeitlicher Imperien. Herrschaftsmanagement jenseits von Staat und Nation: Institutionen, Personal und Techniken, Berlin/Munich/Boston: De Gruyter Oldenbourg, 2015.

Wessely, J. Der Banater Bergbau von 1717-1780 und seine bevölkerungspolitische Bedeutung, Vienna:. Diss., 1937.

Wolf, J. 'Zur Genese der historischen Kulturlandschaft Banat. Ansiedlung, Siedlungsgestaltung und Landschaftswandel im Banat vom frühen 18. bis Anfang des 20. Jahrhunderts', in: Engel, W. (eds.), Kulturraum Banat. Deutsche Kultur in einer europäischen Vielvölkerregion, Essen: Klartext Verlag, 2007, 13-70.

Zedinger, R. Franz Stephan von Lothringen (1708-1765), Vienna/Cologne/Weimar: Böhlau, 2008.

\author{
SABINE JESNER \\ Univerzitet u Gracu \\ Istorija i antropologija Jugoistočne Evrope

\section{KADROVSKA POLITIKA U VREME KRIZE: AUSTRIJSKI BANAT I AUSTRIJSKO-RUSKO-TURSKI RAT (1736-1739)}

\title{
Rezime
}

Sa administrativne tačke gledišta rat predstavlja ogroman izazov za državu. Svi kadrovski kapaciteti moraju da se uposle u ratne svrhe, a upravljanje provincijskom regijom koju je direktno zahvatio rat postaje složenije. Službenici koji su u to bili uključeni dobijali su sve više zadataka koje su morali da efikasno izvrše radi interesa države. Upravljanje krizom postao je ključni koncept u ovim procesima. Temišvarski Banat obezbeđivao je kako službenike, tako i prirodne resurse, što nije uvek bilo lako u ovoj provinciji uništenoj ratom. Tokom rata glavne dužnosti su bile usredsređene na vojne zalihe. Administrativno osoblje na svim nivoima hijerarhije je bilo angažovano na ovome. Otpuštanje osoblja nije bilo predviđeno kao vanredna mera, već se prihvatalo zdravo za gotovo. Stepen smrtnosti zbog kuge i rata neizostavno je doveo do mera restrukturiranja, što se može videti u privremenim rešenjima koja su bila zasnovana na improvizaciji. Velik protok službenika je pratio ovaj proces, što je dovelo do toga da su vlasti u Beču izgubile uvid i kontrolu nad kadrom u Banatu i da su stoga stalno tražili podatke o zaposlenima. Bečki sud je 1739. godine doneo regulative koje su imale socijalne dimenzije. Razni aspekti socijalne politike prema zaposlenima su postali opipljivi, što je u stvari bilo pokrenuto određenim brojem zahteva za finansijsku pomoć ili nove poslove, naročito od službenika u Srbiji ili Vlaškoj, što je došlo do bečkog suda. Izgledalo je kao da će ove mere da obezbede integraciju ovih službenika koji su ne svojom krivicom ostali bez posla u birokratskoj mašini Banata.

Ključne reči: Kadrovska politika, temišvarski Banat, Austro-tursko-ruski rat (1736-1739), birokratija, upravljanje krizom. 